Historic, Archive Document

Do not assume content reflects current scientific knowledge, policies, or practices. 



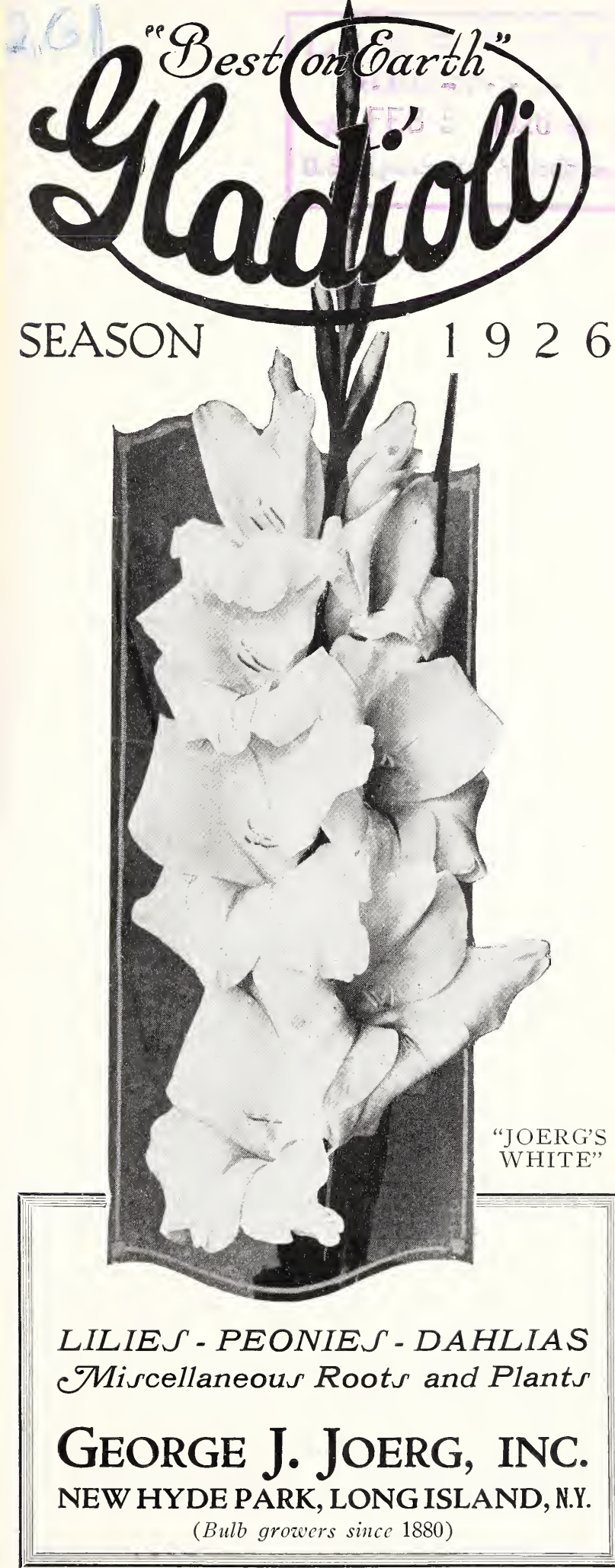




\section{T E R M S}

Cash or satisfactory references required from all correspondents unknown to us.

REMITTANCES should be made by Post Office Money Order, Express Money Order, or Check. If currency is sent, the letter should be registered. Do not send coin or stamps. We disclaim all responsibility when remittances are not made as above directed.

A1l Bulbs, Roots and Plants purchased at "Each" and "Dozen" rate are sent prepaid. Hedge Plants are sent by express-"charges collect."

Packing and Delivery free of charge, post free or express charges prepaid.

We guarantee all stock to be of the very highest quality, and true to name, and although we exercise the greatest care in filling orders, an error may once in a while occur, in which case we will gladly replace stock incorrectly named.

\section{Brief Notes on Growing Gladioli}

Gladioli are probably the most easily grown of all Summer Bulbs, and with ordinary care will give a succession of flowers from July until October. They thrive in almost any soil and location, but prefer a sandy loam in full sunlight. Bulbs may be planted in solid beds of harmonizing shades, in groups among hardy plants, or in single or double rows by the sides of Paths or Drives.

Plant from $6 "$ to $8^{\prime \prime}$ apart and from $4^{\prime \prime}$ to 6 " deep. Make the first planting in April, and continue every two weeks to put in some more, up to June 15 th. This ensures a succession of bloom from July until frost.

Good cultivation will repay in large and prolific blooms. Keep the surface of the soil broken; it helps the growing of the flower spike, and keeps the weeds in check. Water frequently during the dry Summer morths; do not use any stable manure. Lime, dug into the ground before planting, and bone meal worked into the top soil, after the plants are $8^{\prime \prime}-10^{\prime \prime}$ high, are the only fertilizers needed. When cutting Gladioli, leave at least 4 to 6 leaves on the stem; this is essential to the development of the new bulb forming under ground. 


\section{INTRODUCTION}

$\mathrm{O}$

F the many Flower Bulbs, Roots, Plants and miscellaneous stock growing on our spacious Long Island Farm, GLADIOLI have long been associated with our name, as being our great specialty. Perhaps we have given preference to them-not so much in care and attention (we give all our stock equal care) but in experimenting, testing and cross fertilizino (hybridizing); we have done more with Gladioli in this respect, and have raised and introduced many notable seedlings.

\section{Our Gladiolus Novelties}

From the hundreds of seedlings we are now growing, we are distributing seven this year. With the exception of Joerg's White, none have been publicly exhibited until 1924 .

"Joerg's White," "White Prim" and "George J. Joerg," we believe, stand supreme as distinctive novelties in their respective colors. Rather a bold statement to make, but we have paid big prices to other growers for their novelties of like shades, for comparison in our trials, but have found nothing to be afraid of.

\section{Our Standard Varieties of Gladioli}

comprise practically all the better varieties in commerce. Long Island has for years been the chief growing center for the best Gladioli on New York market. Its soil and climate are especially suitable to vigorous growth, and the production of those thick, high-crowned bulbs so much wanted by all lovers of Gladioli.

In addition to the large stocks of Gladioli, we have very representative stocks of Dahlias, Paeonies, and Lilies, and many rare species of other flowering bulbs.

Our catalog will bear careful study, and we are sure some of our friends will find many delightful flowers described, not usually found in commerce.

We solicit your business, with the full confidence of being able to serve you in a manner thoroughly pleasing to you-perhaps a little easier on your pocket book, but more important still, provide you with bulbs that for health and vigor are unsurpassed by any others in the country.

GEORGE J. JOERG, Inc.

${ }^{*}$ Leonard Joerg, President Wm. E. Joerg, Secretary John Joerg, Vice-President Leonard C. Joerg, Manager George J. Joerg, Treasurer

* Growing Gladioli since 1880 
GEORGE J. JOERG, Inc., NEW HYDE PARK, L. I., N. Y.

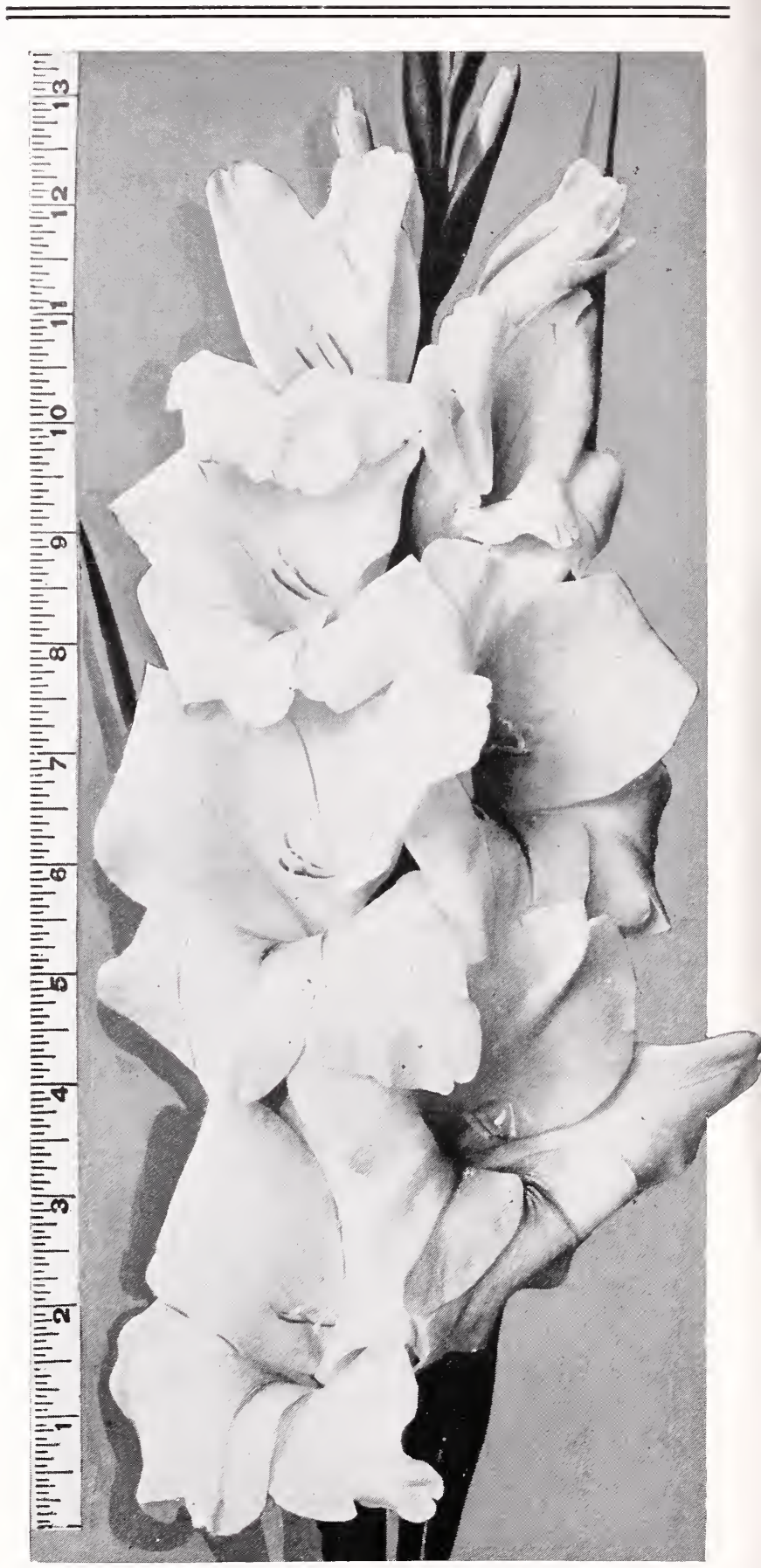

JOERG'S WHITE

The immensity of the bloom can be visualized by comparison with inch rule at left. 


\title{
Gladiolus-“Joerg's White"
}

(1925 Novelty)

Still the greatest white Gladiolus today

\begin{abstract}
Awards from New York Horticultural Society
First Prize 1922 First Prize 1923 First Prize 1924
\end{abstract}

American Gladiolus Society

A. G. S. Trophy, New York 1924

This is unquestionably one of the largest flowered Gladiolus ever introduced and easily the finest and purest of all white varieties.

The Spike. Ordinary spikes, cut in the field without any special culture or attention, measure on an average of 18 to 20 inches from the base of the lower flower to the tip. The flowers are arranged in such perfect formation, all facing one way, as to lead one to believe they were artificially placed there by man, but nature has done her work far more perfectly than the most expert florist could arrange them. The spike reproduced on page 4 was cut with 8 others in the field on August 25 th, after practically 6 weeks' drought, and no irrigation of any kind had been given the plot. Seven perfect flowers with two bursting buds are seen on an 18 inch spike.

The Flower. The lower flower on this spike measured $5 \frac{1}{2}$ inches across. It is of the purest glistening snow-white. Five petals in each flower show no other color whatsoever. The lower petal shades to a creamy yellow in the throat, with light crimson veinings.

The Plant. A very vigorous robust grower, with flower stems averaging 36 inches, two and often three spikes to a large bulb.

Its Merits. As an exhibition flower it so far outclasses every other white that it is a certain winner. Blooms exhibited at the New York Gladiolus Show August 22-23, 1924, won highest awards both from American Gladiolus Society and New York Horticultural Society. It was the outstanding novelty of the Show.

As a garden plant its noble spikes, erect and vigorous, make a wonderful showing, and as a cut flower it is ideal in vases, the perfect formation of the spike making it an easy and very effective one to arrange. Blooms sold on New York market (when a glut of Gladioli prevailed) brought five times the price of the best of all other commercial varieties.

No flower that we have ever raised during our 45 years' experience carried with it so much genuine merit or earned our implicit confidence so much as this Gladiolus. We know it will more than merit the best description we can put in words, or the best photographic reproduction that can be produced with ink and paper.

Introduced in $\mathbf{1 9 2 5}$ at $\$ \mathbf{\$ 5 . 0 0}$ per bulb; now only $\$ \mathbf{3 . 5 0}$ per bulb

(Read comments on next page) 


\section{Extracts from Trade Publications and Other Opinions Expressed About Our Novelties}

From the Florist's Exchange, Aug. 30, 1924

(New York Show)

"The American Gladiolus Society trophy offered for six white was a snip for George J. Joerg, New Hyde Park, L. I. His new JOERG'S WHITE was in very good shape, but we haie seen it much larger. Dry weather has been a drawback to Long Island growers this season.

"George J. Joerg was given a special for several vases of his GIANT WHITE GLADIOLUS, a pure WHITE PRIMULINUS and the striking LA COURONNE."

\section{Issue of Sept. 27, 1924}

"JOERG'S WHITE and JOERG'S WHITE PRIM., raised by George J. Joerg, New Hyde Park, N. Y., both won highest honors' at the A. G. S. show, New York. Both are wonderful flowers. 'Woolgatherer,' who grew and photographed these flowers, say's they are the best in their class; truly white, the large sort having flowers 6 inches across and of great substance."

All eyes were focused on our Novelties at the big New York Show. Here are a few excerpts from letters that reached us soon afterwards:

An old friend of mine attended the N.Y. Glad. show, and told me the best variety in the show was one exhibited by you called "Joerg's White." Would very much like to have your catalog. H. I. B., Dowagiac, Mich.

Sept. 5, 1924.

Saw your exhibit at recent $N . Y$. show and liked" "Joerg's White" very much. S. J. S., New York City.

Aug. 28, 1924.

On my visit to the N. Y. Glad. show I took due note of your seedling No. 10, "George J. Joerg." Kindly advise me of the price; am also partial to your "Joerg's White." E. B. L., Westfield, N.J.

Aug. 28, 1924. I saw your wonderful Glad. "Joerg's White" at the big New York show. I congratulate you upon producing such a wonderful flower. C. E. H., Danbury, Conn.

Aug. 26, 1924.

I attended the Glad. show in New York and was taken by your "Joerg's White." Its size and pure color was of course apparent. E. W. G., Trenton, N. J.

I was told that you were at the show last week. 26, 1924. sorry not to have seen you, but I saw a very beautiful flower. "Joerg's White." I shall be glad to know if you are putting it on the market. E. M. S., Madison, N.J. 


\section{Seedling No. 721, "Joerg's White Prim."}

(Rated Ex. 95; Com. 96, by Chas. E. Gersdorff, Washington, D. C.)

An entirely new break in this beautiful and extremely popular class. It is the only pure White Primulinus in existence. A few blooms exhibited at New York Gladiolus Show, August 22-23, 1924, easily carried off highest award and received special mention both from the Gladiolus Association and New York Horticultural Society as a distinct and highly meritorious novelty.

The plant inherits the typical light graceful spike of the Primulinus family, while the flowers, of perfect Primulinus form, are of the purest snow-white. The lower petals are pale yellow down in the throat, with the faintest rose veinings. We predict a great future for this lovely Gladiolus, at present for the Exhibition table and private garden, but later it is bound to become a great commercial flower on account of its earliness and the fact that all Primulinus can be bloomed earlier under glass than the large flowered types.

Price, Each \$5.00

\section{Seedling No. 10, “George J. Joerg"}

We have seen no flower in the pink Gladioli that approaches this sterling novelty in form, size and color, and the New York Horticultural Society are evidently of the same opinion, for it immediately won their hearts and a medal at their Gladiolus Show August $22-23,1924$. It is a brilliant flower, the bud being at first intense carmine-scarlet, toning out as it develops into a beautiful rich salmon-pink. Each petal has a distinctly blanched central rib, the lower petal shows a perfect triangular tongue of creamy yellow, the apex to the front, the base passing abruptly to a rich fiery scarlet zone with a central deep crimson-maroon blotch. It is almost impossible to describe the rich effect of these various shades exhibited in the one flower; the whole forms a pleasing combination of wondrous beauty, with salmon predominating.

Price, Each \$5.00

\section{"Joerg's Favorite"}

A most uncommonly handsome seedling, particularly for those who adore brilliant art colorings. The ground color is a pale cream, feathered and splashed with bright crimson veins and blotches, a remarkable blend when contrasted with the bright orange throat. The flowers are perfectly formed, slightly crinkled and all face one way in a compact spike. It is a plant of extremely vigorous constitution, the flower spikes practically needing no artificial support.

Price, Each \$2.50 


\section{Seedling No. 921, “Arlene” (Joerg)}

A most uncommon color in Gladioli and bound to be pleasing to the ladies. The ground is a uniform pale rose-pink shading in the throat to a pale fleshpink, with deep crimson base.

The lower petals are marked on the inner twothirds with a bright, velvety, crimson-scarlet zone, which extends clear across the petal in a semi-circular form and extends way down into the throat. The petals are round and overlap to form a full flower of beautiful outline. This variety carries our highest recommendation as a splendid novelty for exhibition or for the garden.

Price, Each \$2.50

\section{Seedling No. 911, “Joerg's Yellow Prim.”}

(Rated Ex. 93, Com. 94, by Chas. E. F. Gersdorff, IT ashington, D. C.)

A new and distinct Primulinus.

A marked improvement on the best of the yellow types.

This plant throws up a flower spike 5 feet high, carrying 12 to 18 large pure yellow flowers, with just one faint crimson mid-rib on the lower petal.

The flowers are extremely large, wide-open, without that "hooded" appearance of the old Primulinus types. With the ever-increasing popularity of this highly decorative class, we believe "Yellow Prim." will be accepted as a remarkable meritorious improvement to the class.

Price, Each \$2.50

\section{Primulinus "Phantasy" (Joerg)}

(Rated Ex. 94, Com. 96, by Chas. E. F. Gersdorff, II ashington, D. C.)

A new and very attractive color, distinct from all other Primulinus. Color is a clear salmon with coral margin, buds are brilliant orange-scarlet. Two lower petals are pale primrose-yellow, edged pink, with crimson-reined throat. The upper petal folds back, thus forming a very open flower. Extremely early cut-flower variety.

Price, Each 60c

\section{SPECIAL OFFER}

One bulb of each of the foregoing Novelties, seven altogether (including the sensational "Joerg's White"). Price, $\$ \mathbf{1 8 . 0 0}$

(Bought separately' would cost $\$ 21.60$ )

(No bulblets or planting stock of any Novelties for sale)

\section{GLADIOLUS SEED}

Each year we save large quantities of seed from choice varieties. Most interesting colors are often raised, and now and again a variety of great merit may surprise you. Per pkt. (150 seeds) 50c 


\section{GENERAL LIST OF}

\section{Standard Named Gladioli}

America. Beautiful lavender-pink.

Each 10c; doz. \$1.00; $100 \$ 4.50$

Alice Tiplady (Primulinus). Bright orange, large open flowers, graceful stems; splendid decorative cut flower. $\quad$ Each $\mathbf{2 0 c}$; doz. $\$ 2.00 ; 100 \$ 10.00$

Anna Eberius. Deep velvety-purple with deeper throat; splendid spike.

Each 25c; doz. \$2.50; $100 \$ 16.00$

Attraction. Rosy crimson with white throat; well formed spike. Each 15c; doz. \$1.50; $100 \$ \$ 9.00$

Arizona Rose. Clear rose-pink; large flower and spike.

Each 10c; doz. \$1.00; $100 \$ 6.00$

Autumn Queen. Almost a white, with scarlet blotch on lower petal.

Each 20c; doz. \$2.00; $100 \$ 10.00$

Augusta. One of the old whites; still a good cut flower variety. Each .06; doz. 60c; $100 \$ \mathbf{\$ 4 . 0 0}$

Baron J. Hulot. Dark violet-blue; one of the best of this shade. Each 10c; doz. \$1.00; $100 \$ \$ 8.00$

Ben Lomond. Clear yellow, lower petals golden olive, with garnet stripe. $\quad$ Each 25c; doz. \$2.50

Bertrex. Pure white with lavender hue in throat.

Each 15c; doz. \$1.50; $100 \$ 9.00$

Blue Jay. A very fine lavender-blue with milky-white throat; a great favorite.

Each 20c; doz. \$2.00; $100 \$ \mathbf{\$ 1 0 . 0 0}$
Brenchleyensis. spike; splendid for cutting.

Each .06; doz. 60c; $100 \$ 4.00$

Catharina. An early flower of a beautiful lavender shade with heliotrope blotch.

Each 30c; doz. \$3.00

Candidum. Large white blooms, with gracefully reflexed petals. Each 10c; doz. \$1.00; $100 \$ 8.00$

Canary Bird. Clear yellow, dwarf habit; compact spike. Each 15c; doz. \$1.50

Carmen Sylva. Tall, graceful, well-arranged spike of white flowers, slightly veined violet.

Each 25c; doz. \$2.50

Chicago White. A well known market variety; good under glass. Each 10c; doz. \$1.00; $100 \$ \$ 6.00$

Contrast. Bright crimson-scarlet, flamed white; very fine spike. $\quad$ Each 25c; doz. \$2.50

Crystal White. Clear white; early flower, not very large. $\quad$ Each 10c; doz. \$1.00; $100 \$ \$ 8.00$

Crimson Glow. Rich crimson; large open flower and good spike. $\quad$ Each 15c; doz. \$1.50

Columbia. Orange-scarlet, feathered crimson.

Each .06; doz. 60c; $100 \$ 4.00$

Diana. A beautiful flower of rich crimson; perfect shape and large spike. Each 30c; doz. \$3.00

Dorothy McKibbin. A ruffled type; rich pink, mottled rose. $\quad$ Each $10 c ;$ doz. $\$ 1.00 ; 100 \$ 8.00$

Empress of India. Deep crimson-maroon; one of the darkest of all "Glads." Each 15c; doz. \$1.50

E. J. Shaylor. Rose pink, intensified at outer edges of petals, which are prettily ruffled.

Each 15c; doz. \$1.50 
Evelyn Kirtland. Rich rosy-pink, tipped red, with lighter shade in throat; lower petals blotched with crimson. Each 15c; doz. \$1.50; $100 \$ \$ 9.00$

Fascinator. Salmon-pink, tinted carmine with paler throat. $\quad$ Each $15 c ;$ doz. \$1.50; $100 \$ \$ 9.00$

Fire King. Rich fiery scarlet; very effective cut flower. Each 10c; doz. \$1.00; $100 \$ 6.00$

Flora. Clear canary-yellow; large wide-open flowers.

Each $15 \mathrm{c} ;$ doz. \$1.50

Giant White. A good white, but only a "pigmy" compared to "Joerg's White."

Glory of Noordwijk. A clear creamy-yellow; rather good for this shade. Each 25c; doz. \$2.50

Golden West. Rich orange with lavender and white margins. Each 10c; doz. \$1.00; $100 \$ 6.00$

Golden King. Clear yellow with crimson blotch in the throat. Each 10c; doz. \$1.00; $100 \$ \$ 8.00$

Golden Gate. Golden-orange, throat feathered red.

Each 25c; doz. \$2.50; $100 \$ 18.00$

Golden Measure. One of the best in the yellow class; large flowers of rich golden-yellow.

Each 50c; doz. \$5.00

Gold. Rich yellow, with deep golden throat; faintly streaked; flowers are large on a well-formed spike.

Each 50c; doz. \$5.00

Gretchen Zang. Tall spike of geranium-pink, with carmine stripes in throat.

Each 15̄c; doz. \$1.50; $100 \$ 9.00$

Grenadier. Bright scarlet flowers on good spike.

Each 10c; doz. \$1.00; $100 \$ 8.00$

Halley. Lovely salmon-pink. Early, good under glass. Each .08; doz. 80c; $100 \$ 5.00$

Herada. A much fancied shade of deep lilac-mauve.

Each 15c; doz. \$1.50; $100 \$ \$ 9.00$

Ida Van. Bright red shading to carmine-pink.

Each .08; doz. 80c; $100 \$ 6.00$

I. S. Hendrickson. White, flamed bright pink.

Each 25c; doz. \$2.50; $100 \$ 16.00$

Jewel (Primulinus). A fine salmon-pink with goldenyellow throat.

"Joerg's White." (See Novelties.)

June. White ground, flamed and splashed with pink.

Each 25c; doz. \$2.50

La Couronne. A very striking flower of beautiful creamy-white, edged creamy-yellow, lower petals blotched dark maroon. Each 25c; doz. \$2.50

Le Marechal Foch. Apple-blossom pink with carmine center; huge flowers well placed on spike; early.

Each 10c; doz. \$1.00

Lily Lehman. Ivory-white, lily-shaped flowers; early.

Each 10c; doz. \$1.00; $100 \$ 8.00$

Liebesfeuer. Large flowers of brightest scarlet.

Each 30c; doz. \$3.00

Loveliness. Pale cream suffused with apricot.

Each 15c; doz. \$1.50

Marshal Foch. (K.) Salmon-pink with salmonscarlet margins; huge flowers on good spike.

Each 50c; doz. \$5.00

Mary Fennell. Tall, light-lavender with primrose throat; splendid and attractive cut flower.

Each 15c; doz. \$1.50 
"Best on Earth" G L A D I O L I

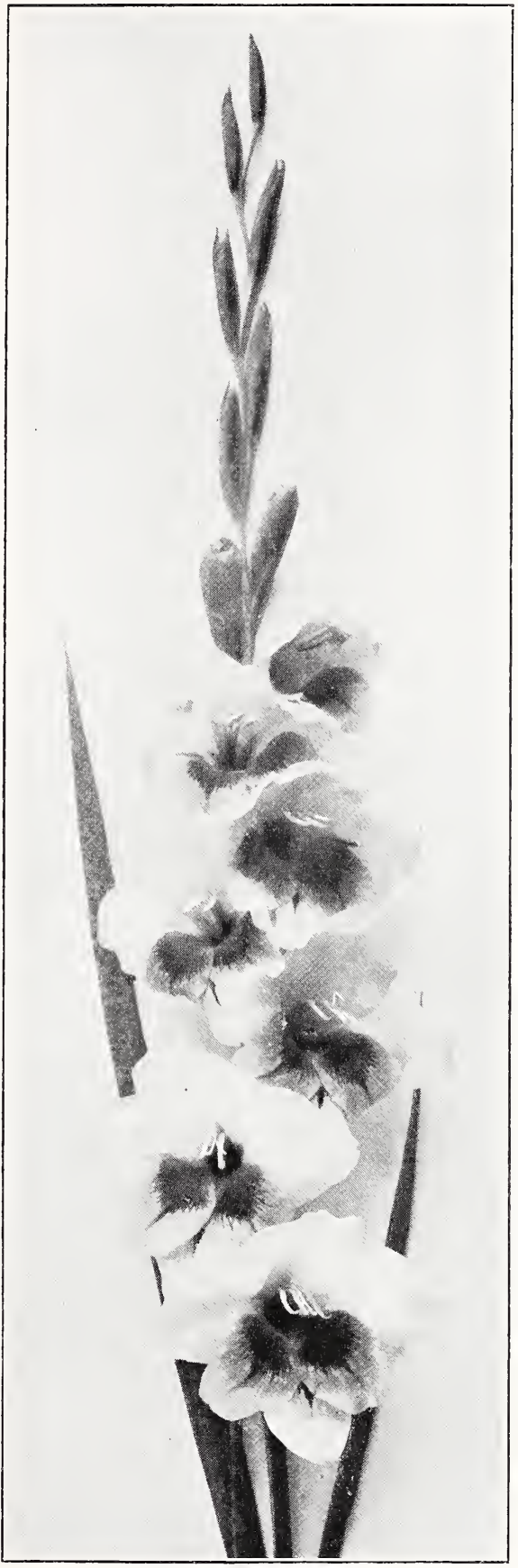

LA COURONNE

A delightful contrast of color;

a flower much in demand by New York's leading florists. 
Maiden's Blush (Primulinus). A free-flowering and exceedingly early variety of exquisite blush-pink. Best of all under glass. Each 15c; doz. \$1.50

Mephisto. Bright orange-scarlet; a brilliant and uncommonly handsome garden variety.

Each 25c; doz. \$2.50

Miss Helen Franklin (Ruffled). A good white with faint lavender markings; flowers well placed on stem. Each 10c; doz. \$1.00; $100 \$ \$ 8.00$

Mr. Mark. Clear lavender-blue with violet blotch.

Each 15c; doz. \$1.50; $100 \$ 10.00$

Mrs. Frank Pendleton. A variety of extreme beauty and wide popularity. Color is clear rose with crimson blotches. Each 15̃c; doz. \$1.50

Mrs. Dr. Norton. Creamy-white, tipped pink, with pale yellow throat. A very handsome "picotee"like flower.

Each 15c; doz. \$1.50

Mrs. F. C. Peters. New. Delicate rosy lilac edged white, with central crimson blotch.

Each 50c; doz. \$5.00

Mrs. Frances King. Brilliant vermillion-scarlet; tall spike makes it a splendid and effective cut flower.

Each 10c; doz. \$1.00; $100 \$ 6.00$

Mrs. H. E. Bothin. White, flamed with pink, with deep scarlet throat; ruffled petals.

Each 50c; doz. \$5.00

Mrs. Velthuys. Deep crimson-scarlet; large flowers on fine spike. Each 25c; doz. \$2.50

Nezinscott. Bright blood-red, with deep crimson blotch. Each .08; doz. 80c; $100 \$ \$ 6.00$

Niagara. Cream and canary-yellow, splashed carmine. Each 10c; doz. \$1.00; $100 \$ 8.00$

Orange Glory (Ruffled). Bright orange with paler throat; an exquisite color and splendid spike.

Each 30c; doz. \$3.00; 100 \$18.00

Panama. Light rosy-pink; early; good for cutting.

Each 10c; doz. \$1.00; $100 \$ 8.00$

Peace. White with lighter throat; tall, vigorous grower. Each 10c; doz. \$1.00; $100 \$ 8.00$

Pink Beauty. Rosy-pink with crimson blotches; extremely early. Each .08; doz. 80c; $100 \$ \$ 6.00$

Pink Perfection. Delicate apple-blossom pink; large flowers on a graceful, tall, wiry stem.

Each 15c; doz. \$1.50; $100 \$ \$ 9.00$

Pink Wonder. Large, pointed flower of clear pink; good spike. Each 25c; doz. \$2.50

Polar Star. A white variety that came from the coast with a great reputation. Our "Joerg's White" surpasses it in every way, size, purity and form.

Each 25c; doz. \$2.50

Primurella. Cream and peach-pink; lower petals yellow, striped carmine. Each 15c; doz. \$1.50

Princeps. Rich crimson-scarlet with white throat and markings. Each 15c; doz. \$1.50; $100 \$ \$ 9.00$

Prince of Wales. An early, large-flowered variety of a delightful salmon shade.

Each 15c; doz. \$1.50; $100 \$ 9.00$

Princepine. Brilliant carmine with large white triangular blotch. Each 12c; doz. \$1.20

Princess V. Louise. Rose pink, salmon throat, tall spike; very fine. Each 30c; doz. \$3.00

Purple Glory. A glorious "Glad."; rich rose deeply suffused with purple, with a velvety-purple throat.

Each 30c; doz. $\$ 3.00$ 


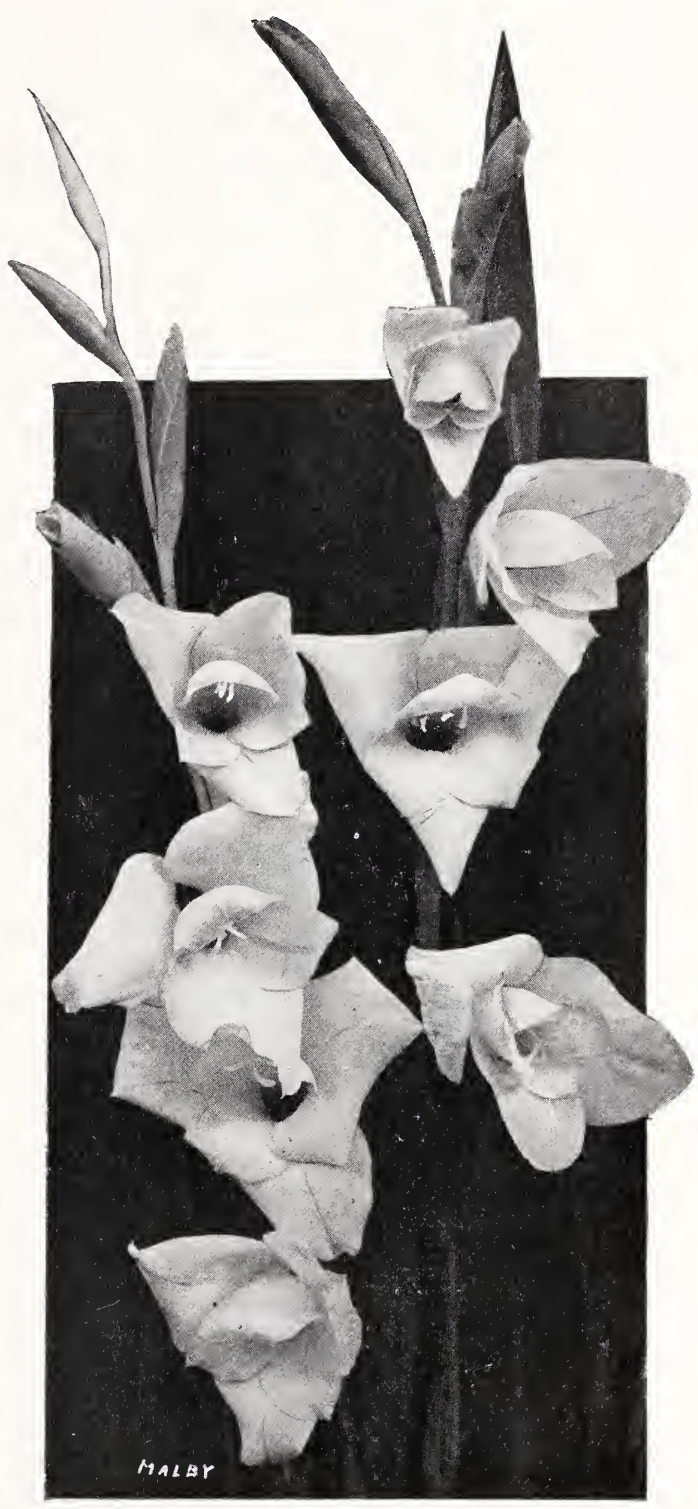

Primulinus "SOUVENIR"

Radiance. Verv fine rosy pink; enormous flowers. Each 25c; doz. \$2.50

Rosella. Large vigorous spike; flowers are pale rosepink with white throat.

Each 12c; doz. \$1.20; $100 \$ 9.00$

Rose Wells. Large open blooms, pale rose with lilacrose blotch.

Each 12c; doz. \$1.20

Ruby King. Intense, dark, ruby-red.

Each 25c; doz. \$2.50 
Scarlano (Ruffled). A brilliant and most striking flower of rich orange-red.

Each $25 \mathrm{c} ;$ doz. $\$ 2.50 ; 100 \$ \$ 16.00$

Scarsdale. Lavender-pink, shading to old rose; wide open flowers, good spike.

Each 10c; doz. \$1.00; $100 \$ 8.00$

Schwaben. A vigorous spike, with large compact mass of flowers; color clear yellow with crimson throat. Each 12c; doz. \$1.20; $100 \$ 8.00$

Scribe. White streaked with crimson.

Souvenir (Primulinus) Each 15c; doz. \$1.50 low; tall, graceful spike. Each 25c; doz. \$2.50

Sulphur King. Clear sulphur-yellow; large-flowered. Each 20c; doz.\$2.00

Scarlet Princeps. Large spike of massive crimsonscarlet flowers, 5 to 6 open at one time.

Each 50c; doz. \$5.00

Twotint. Pink, shaded white, suffused with yellow.

Each 30c; doz. \$3.00

Velvet King. Deep velvety-crimson flowers in a well-shaped spike. Each 15c; doz. \$1.50

White Giant. Pure white, with reflexed petals.

Each 15c; doz. \$1.50

White Glory (Ruffled). Fine white with pale blue throat; very attractive spike. Each 30c; doz. $\$ \mathbf{\$ 3 . 0 0}$

Wild Rose. Deep rosy-pink with crimson stripe.

Each 10c; doz. \$1.00

Winsome. Blush pink, shaded carmine; large round flowers in a fine spike. Each 25c; doz. \$2.50

Wilbrink. Pale rosy-pink; very early.

Each .08; doz. 80c; $100 \$ 6.00$

Wm. Falconer. Clear, light pink; very attractive shade. $\quad$ Each $10 c ;$ doz. $\$ 1.00 ; 100 \$ 8.00$

\section{JOERG'S MIXTURES OF GLADIOLI}

These mixtures are composed of very choice varieties, and are splendid value for filling in, in mixed borders and beds. They are splendid for cutting, and should be planted in quantity, especially for indoor use.

White and Light Shades. Doz. \$1.00; $100 \$ \$ 6.00$

Pink Shades.

Yellow Shades.

Red and Scarlet.

Joerg's Seedlings.

Primulinus Hybrids.

Popular Mixture.

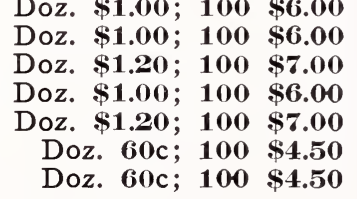

\section{"Surprise" Gladiolus Collection}

This collection is offered to those who desire to plant liberally for cut flowers.

10 bulbs, all sure bloomers ( $1 \frac{\mathrm{T} / 4}{4}$ in. assortment, prepaid anywhere in the U. S., for (Cash, Check

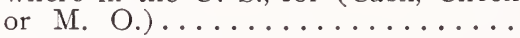

(Or 30 bulbs for small gardens, $\$ 1$.) 

H A R D Y
G A R D E N
L I L I E S

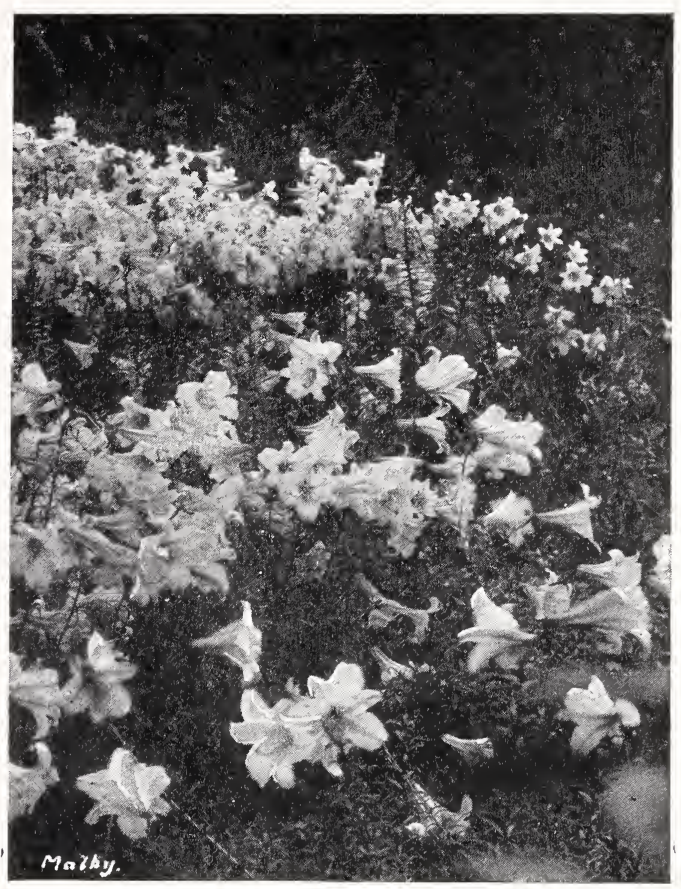

\section{LILIUM MYRIOPHYLLUM "The Regal Lily"}

\section{Hardy Lilies}

We have been growing Lily bulbs for almost half a century and by careful culture in a loam that is extremely suitable to most native varieties and many foreign types, we have been very successful in producing the finest bulbs. Many leading jobbers and dealers in these bulbs have for years been obliged to fall back on us for their bulbs, when other usually reliable sources reported crop failures. Others have, year in and year out, purchased Joerg's Bulbs.

Hardy Lilies are more in demand today than ever; their beautiful colors and stately spikes make them invaluable for beds and Herbaceous Borders.

CANADENSE. June-July, $3 \mathrm{ft}$. A very beautiful and inexpensive lily for massed plantings. Flowers vary from orange-red to yellow and are thickly spotted. Each 15c; doz. \$1.50

DAVURICUM. June-July, 2-3 ft. Bears its flowers in umbel form, of from 3 to 5 blooms on a stem. Color bright scarlet; a very handsome and showy lily. Each 12c; doz. \$1.20

Luteum. A splendid and extremely uncommon June-flowering lily; flowers are rich yellow, heavily spotted black. Each 20c; doz. \$2.00 


\section{Hardy Lilies-Continued}

ELEGANS Robustum (Marmoratum Aureum). 1I/2 ft., July. Clear apricot, spotted purple; broad, wide open flowers. Each 15c; doz. \$1.50

Leonard Joerg. Rich apricot with dark wine-red spots. Each $\mathbf{3 0 c}$; doz. $\mathbf{\$ 3 . 0 0}$

Bicolor. Orange with scarlet margin; lightly spotted. Each 50c; doz. \$5.00

HANSONI. June, $3 \mathrm{ft}$. The yellow Japanese Martagon Lily. Flowers are golden-yellow, heavily spotted crimson-maroon. Each 75̃c; doz. \$7.50

HENRYI. Aug.-Sept., 6-8 ft. Huge flower stems bearing large branching heads of pale orangeyellow flowers; requires deep planting.

Each $\mathbf{8 0 c}$; doz. $\mathbf{\$ 8 . 0 0}$

MYRIOPHYLLUM (Regale). The "Regal Lily." One of the handsomest and most fragrant of all lilies. Flowers are trumpet-shaped, ivory white and cream inside, with broad reddish band on outside. Each \$1.00; doz.\$10.00

SPECIOSUM Melpomene. A fine example of the lance-leaved lilies. Very hardy, therefore splendid for permanent groups. Color rich carmine with crimson spots. Each 50c; doz. \$5.00

SUPERBUM. July-Aug., 5-6 ft. Large heads of bright orange-crimson flowers with reflexed petals; heavily spotted.

Each 30c; doz. \$3.00

TENUIFOLIUM. June, $1 \frac{1}{2} \mathrm{ft}$. Graceful slender stems with bright scarlet "Turk's Cap" flowers. Each 30c; doz. $\$ 3.00$

Golden Gleam. Flowers similar in form to the preceding, but of a rich apricot color.

Each 80c; doz. $\$ 8.00$

TIGRINUM (Tiger Lily). The well-known orange lily, frequently seen in hardy borders; in bloom in August.

Each 25c; doz. \$2.50 Flore Pleno (Double Tiger Lily). The double-flowered form of the preceding; very handsome and hardy.

Each 30c; doz. $\$ 3.00$

WALLACEI. Aug.-Sept., 2 ft. Usually produces three to five flowering stems bearing rosy apricot-tinted flowers, thickly spotted. A moist situation suits it.

Each 40c; doz. $\$ 4.00$

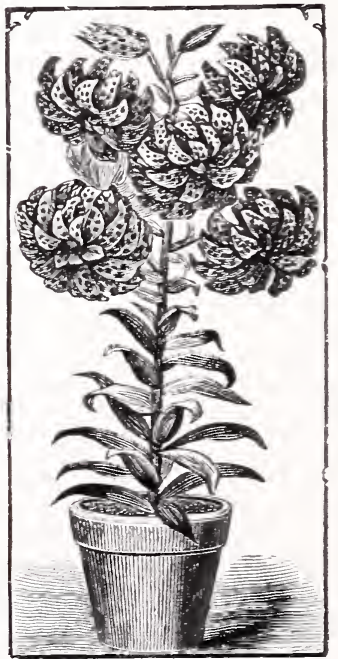

DOUBLE TIGER LILY 


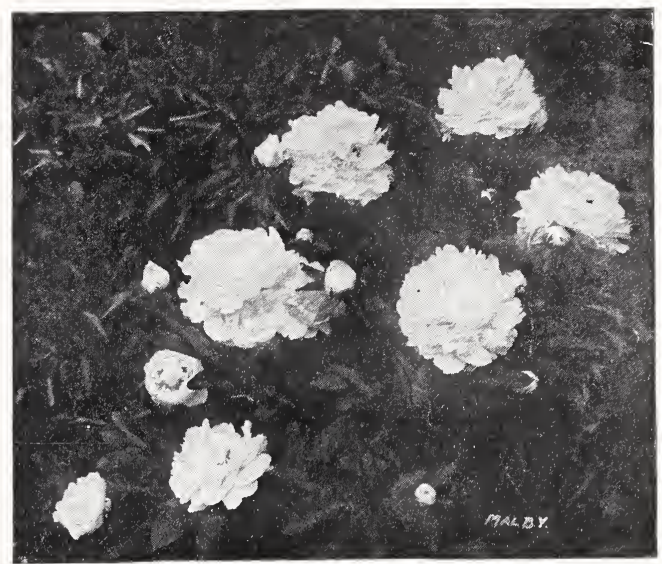

\section{Hardy Herbaceous Paeonies}

Paeonies grow best in light rich loam, but any good garden soil will produce good results. They can be safely transplanted in early Spring also in September and October. The ground should be well prepared, and while well rotted manure is beneficial to them, it should in no case be applied directly to the roots. A good mulching will help them materially. The roots should be set so that the eyes are from two to three inches beneath the surface of the soil. Deep planting is the most frequent cause of blind plants. They never produce the best flowers until the second year after planting and should be left undisturbed for a few years. It is therefore advisable to plant them two and one-half to three feet apart. Paeonies are practically immune from diseases and if strong healthy plants are procured, there is little to fear.

Albert Crousse. Large, well-formed flowers of soft shell-pink with faint salmon tints. Stems tall and strong and a vigorous grower. Very fine as a cut flower. Late.

Each $75 \mathrm{c}$

Alsace Lorraine. Pointed white petals, suffused with a golden light, make this a charming variety. Tall and vigorous grower. Late.

Each \$3.50

Asa Gray. Unique flowers of milk-white thickly sprinkled with minute carmine dots, so that the total effect is delicate pink. Midseason. Each $\mathbf{\$ 1 . 0 0}$

Avalanche. A very fine ivory-white bloom of convex form, center oftentimes splashed with carmine. Excellent as a cut flower. Late midseason.

Each \$1.25 


\section{Paeonies-Continued}

Baroness Schroeder. Rose type; late. White with shadings of flesh. This is one of the finest paeonies. Its immense flowers are of great substance with high chalice-shaped center.

Each \$1.25

Couronne d'Or. Large, full flower of pure white with a circle of golden stamens. A very beautiful variety and valuable as a cut flower. Late. Each 50c

Edulis Superba. Deep rose pink with an occasional crimson marking. Guard petals wider than those in the center. Very early.

Each 50c

Festiva Maxima. Probably the most widely known of any Paeony. Exceptionally large ivory-white flowers of rather feathery appearance, with a fleck of crimson in the center. Midseason. Each 60c

Fragrans. Bomb type, dark pink. Strong, vigorous, free bloomer. Good keeper; very fragrant.

Each 50c

Georgiana Shaylor. Exceptionally large, flat flowers of pale rose-pink with an occasional crimson fleck. Dwarf but sturdy habit. Midseason to late.

Each \$5.00

Humei. Very large, compact globular rose type. Cherry pink with silver tips. Cinnamon fragrance. Very late.

Each 50c

Livingstone. Late. An extra-good variety, having very large, compact flowers of pale lilac-rose, with silver tips, central petals flecked carmine.

Each $75 \mathrm{c}$

Mons. Jules Elie. Immense globular blooms, guard petals recurved, resembling chrysanthemums. Clear medium pink with a silvery tinge. Midseason.

Each \$1.00

Mons. Krelage. Semi-rose type; late midseason. Deep currant or solferino-red with amaranthine center. A superb Paeony.

Officinalis Rubra Plena. This is the old-fashioned red, the most brilliant of all red paeonies; early and splendid cut-flower.

Each 75c

Officinalis Rosea Plena. Large double rose-pink flowers.

Each \$1.25

Philomele. Medium sized flowers of bright rose, guard petals and center and collar of deep creamy yellow. Midseason to late.

Each 75c

Reine Hortense. Large compact flower with broad rounded petals of soft flesh-color, center showing some crimson splashes.

Each \$3.00

Solange. Extra large flowers with broad rounded petals, waxy white, suffused with a reddish golden light. One of the very finest. Late midseason.

Each \$4.00

Stephanie. Semi-double type; midseason. Delicate blush guards shading to white. Extra fine.

Each $\$ 3.00$ 


\section{Japanese Iris}

(Iris Kaempferi)

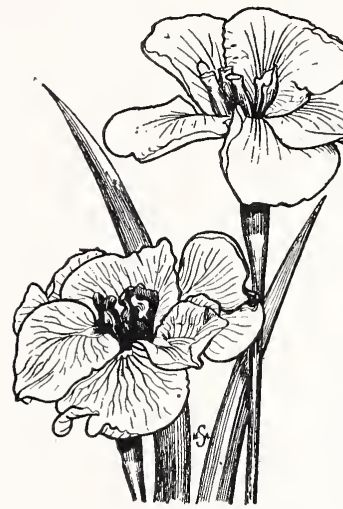

This section of the Iris family embraces wonderful colorings, vivid yet harmonious; all the colors of the rainbow seem to have been gathered together in them in the most fascinating combinations. The great size of the flowers is noteworthy, it being not at all unusual to have blooms 6 to 8 inches across, while there are plenty of instances on record where these marvelous flowers have reached the enormous size of 12 inches across.

A good, well-drained soil will encourage sturdy growth and amazing blooms if they are given plenty of water during the dry season. They come into bloom in July.

(Any orders received too late for Spring delivery will be shipped in the Fall.)

Blue Jay. Idigo blue, with rich yellow base.

Each 75c, doz. $\$ 7.50$

Distinction. Light lavender-pink, bright yellow, blotched at base of petals; three petals.

Gold Bound. Large; pure white, yellow center; six petals.

Helen von Siebold. Reddish violet, veined white, three petals.

Mahogany. Deep velvety, mahogany-red; six petals.

Malmaison. Very large blooms, violet blue with a pale blush-pink base. Each \$1.00; doz. \$10.00

Oriole. Large double flowers of a rich plum-red, shading to deep purple.

Pyramid. Light blue; center of petals veined white; six petals.

Templeton. Double light blue flowers, mottled rose and white.

Toledo. Large, single white blooms with rosy-pink base.

Victor. White, veined violet-blue, purple center; six petals.

Each 50c

PRICES-Any of the above, except where noted, Each 35c; Doz. \$3.50 


\section{HARDY HERBACEOUS PLANTS}

\section{("Old-fashioned Flowers")}

We do not hesitate to give a word of praise to this humble, yet lovely class of plant.

How cheerful they look, even in the smallest garden or yard. On account of their vast number of varieties, in color, and in time of blooming, we can make selections that will produce flowers from early Spring until late in the Fall. Besides, a great number are highly valuable as cut flowers to embellish our homes. Only a few people understand how simple and easy it is to grow a nice collection, as very little care is needed to get good results.

\section{Buddleia Variabilis}

(Summer Lilac or Butterfly Bush) 3-5 ft.

August to October.

In mild climates this is really a hardy shrub, but as our northern Winters usually kill it to the ground, we are including it among Perennial Plants, and one of the best at that. There is no danger of winter killing it if it gets the usual protection of litter or leaves that all herbaceous plants need. Each Spring it throws out vigorous growths that develop all Summer to terminate in August and September in tapering spikes of a beautiful lavender-mauve shade. Give it plenty of room, for in itself it is a perfect model of exquisite form and color. If it does not die to the ground in Winter cut it back each Spring.

Strong roots, each $75 \mathrm{c}$

\section{Chrysanthemums (Hardy Varieties)}

Hardy Chrysanthemums are undoubtedly one of the best of border plants, coming in with a grand display of color and cut flowers when other plants are on the wane. In our estimation one cannot plant too many. From September until frost one can literally gather armfuls from a seemingly inexhaustible supply.

Lillian Doty. Abundant small double flowers, of a delightful shade of pink shading to flesh-pink.

Red Doty. Similar to preceding, flowers are of a dull brownish-red.

White Doty. Pure white double flowers.

Yellow Doty. Rich golden yellow; profuse bloomer.

PRICES-Any of 4h: above, each 30c; doz. \$3.00 SPECIAL-One prant of each color (4) for $\$ 1.00$ 


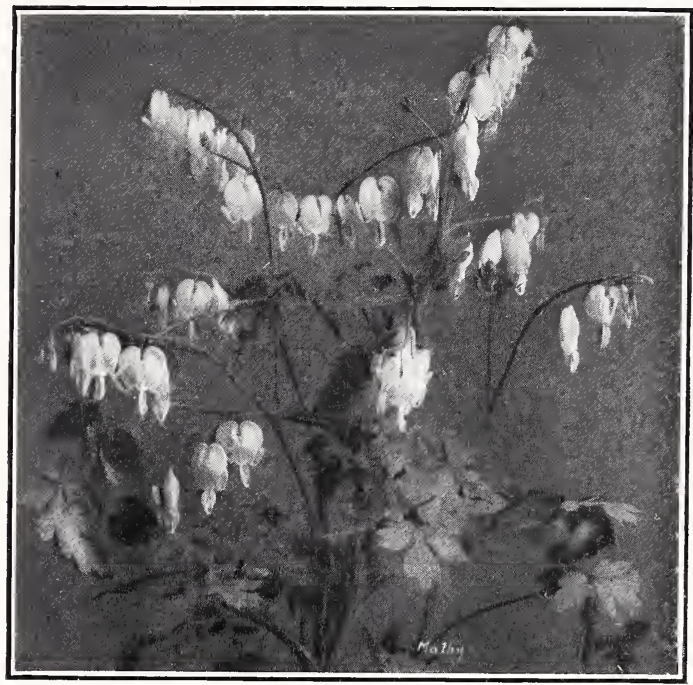

DIELYTRA (Bleeding Heart)

\section{Dielytra Spectabilis}

\section{(Bleeding Heart)}

A favorite border plant because of the quaintness, and delightful shade of its flowers. It grows into pendulous sprays, from which hang, heart-shaped, rosy pink flowers from April to June. Foliage is also very handsome. Used as a border plant, and often lifted in the fall and potted, to force in gentle heat under glass for early spring bloom.

Each 75c; doz. $\$ \mathbf{7 . 5 0}$

\section{Delphinium (Hardy Larkspur)}

Beautiful hardy plants, grown in borders for their stately habit and the handsome spikes of flowers, gorgeous in coloring. Excellent for cutting, and a mass planting is a feature of your garden to be proud of at blooming-time-from June till late fall.

For their successful cultivation, a rich, well-dug soil is necessary, and when planted in groups along the back portion of a border, they produce a splendid effect.

Joerg's Hybrids. Our hybrid Delphiniums are from an extra select English strain of seed, and comprise every known shade in this grand flower.

Each 30c; doz. $\$ 3.00$ 


\section{Hardy Herbaceous Plants-Cont'd.}

\section{Daphne (Garland Flower)}

Handsome dwarf sub-shrubs or herbaceous plants, mostly evergreen, excellently suited for planting near the front of shrubberies, rockeries, etc., with odorous pink flowers, and handsome foliage.

Cneorum. Long procumbent branches, and bright, pink, sweetly-scented blossoms; evergreen foilage. Blooms in April and again in September. $1 \mathrm{ft}$ Strong field-grown, each $\mathbf{\$ 1 . 0 0}$

\section{Euphorbia (Milkwort)}

Corollata (Flowering Spurge). Showy and useful native plant growing about 18 inches high, and bearing from June till August umbels of pure white flowers with a small green eye.

Each 25c; doz. \$2.50

\section{Funkia (Day Lily)}

Very attractive plants with broad overlapping leaves of various markings; very ornamental, surmounted by dainty lily-like flowers in terminal racemes. Effective in front of shrubbery, under trees, or any shady position where they thrive best.

Subcordata Grandiflora Alba. Very large pure white lily-shaped fragrant flowers in August and September.

Each 40c; doz. \$4.00

Variegata. Variegated foliage; blue flowers. Beautiful edging plant. $\quad$ Each 25c; doz. \$2.50

\section{Hemerocallis (Yellow Day Lily)}

The Day Lilies are magnificent hardy plants and are undoubtedly among the finest for ordinary garden culture, as they will grow anywhere in either partial shade or full sun. The flowers are produced in spikes of from six to a dozen blooms, opening in succession, and are very useful when cut for indoor decoration. Good for borders, shrubberies, wild garden or naturalizing in grass.

Thunbergii. Flowers lemon-yellow, very fragrant.

One of the most desirable species.

Each 40c; doz. \$4.00 


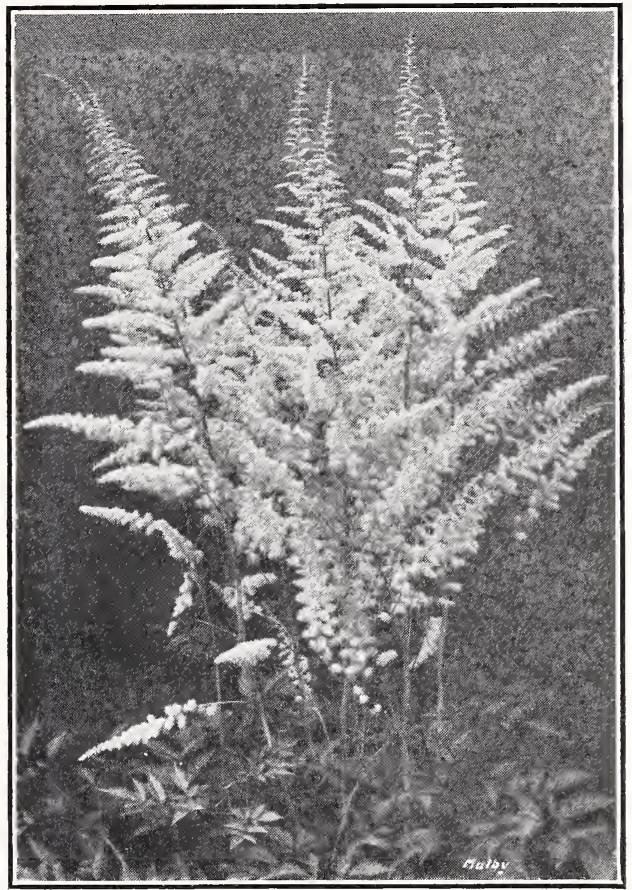

SPIRAEA (Astilbe)

\section{Platycodon (Chinese Balloon Flower)}

Very handsome border plants of the Campanula family, the flowers in bud having the appearance of inflated balloons, they flower from June to September.

Grandiflorum. Large, handsome deep blue flowers. Each 25c; doz. \$2.50

Album. Pure white. Each 25c; doz. \$2.50

Double Mixed. White and blue shades assorted. Each 20c; doz. \$2.00

\section{Spiraea (Astilbe)}

We have a fine collection of these hardy hybrid Astilbes that will thrive in any good rich soil if given plenty of water during the growing season. Flowers in showy panicles, freely produced. June, July.

Roots may be lifted in the autumn and potted up, to provide early spring flowers for Greenhouse and Conservatory.

America. Charming lilac-rose flowers which do not fade, abundant foliage.

Gladstone. Fine spike of pure white.

Japonica. Fine white for garden or greenhouse.

Philadelphia. Clear lavender-rose; exquisite.

Princess Mary. Deep rose-pink, shaded lilac.

Queen Alexandra. Large fluffy pink spike.

Queen of Holland. Beautiful flesh color.

Rubens. Deep carmine-rose.

Price, any of the above, large field-grown clumps, each $75 \mathrm{c}$; doz. $\$ 7.50$ 


\section{Hardy Herbaceous Plants-Cont'd.}

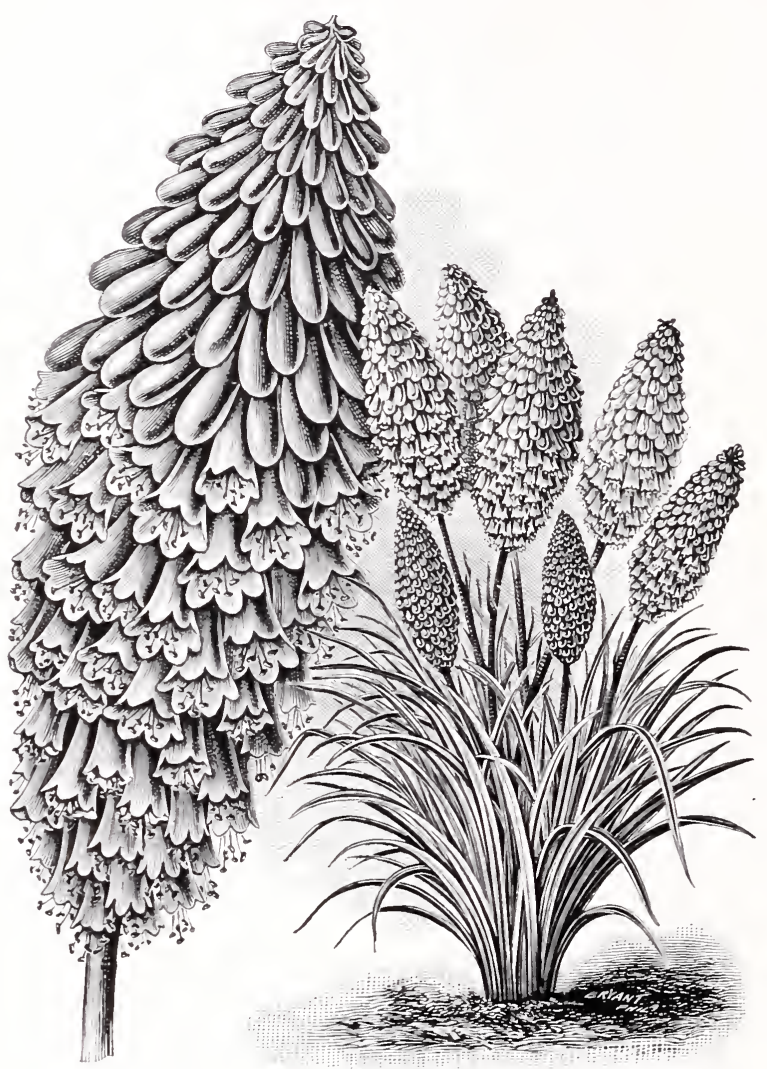

\section{Tritoma (Flame Flower)}

\section{(Red Hot Poker, or Torch Lily)}

Pfitzeri (The Everblooming Flame Flower). The free and continuous blooming qualities of this variety have made it one of the great bedding plants, and when we consider that there are few flowering plants which are suitable for massing under our severe climatic conditions it is little wonder that such an elegant subject should become so popular. Succeeds in any ordinary garden soil, but responds quickly to liberal treatment. Its brilliant orangescarlet spikes, in late summer, stand 3 to $4 \mathrm{ft}$. high. 


\section{Shrubs, Hedge Plants and Climbing Vines}

Azalea Amoena (Japanese Evergreen Azalea). A dwarf shrub with double purplish-red flowers in May; is especially adapted for borders and rock gardens; needs some protection in Northern latitudes. Should be planted in sheltered positions and will abundantly repay for any care given it. Bushy.

Each \$1.00

Amoena Superba. A bright scarlet form of the wellknown and charming A. amcena, but far surpassing it in brilliancy and general beauty; a profuse bloomer; foliage round in shape and evergreen.

Each \$1.25

\section{Climbing Vines}

Apios Tuberosa. Splendid hardy climber. Will grow to a height of 8 to 10 feet, vine and foliage resembling a Wistaria; deep purple color; fragrant.

Each 15c; doz. \$1.50

Clematis Paniculata (Japanese Virgins' Bower). This handsome hardy climber is one of the choicest and most satisfactory climbing flowering plants. Of strong, rapid growth, with small, dense, cheerful green foliage, and pure white, deliciously fragrant flowers, which appear in the greatest profusion in August and September, followed by silvery feathery seed pods, which make an attractive appearance until mid-winter.

Each 35c; doz. \$3.50

Madeira Vine. A fine and rapid climbing vine for porch or trellis.

Each 10c; doz. \$1.00

Wistaria Chinensis (Wistaria). Woody vines with tightly clinging habit, for pergolas, arbors, trellises, etc., especially ornamental in early summer when they are resplendent with their large, drooping clusters of fragrant lilac blossoms.

Strong 2-year plants, each $\mathbf{7 5 c}$

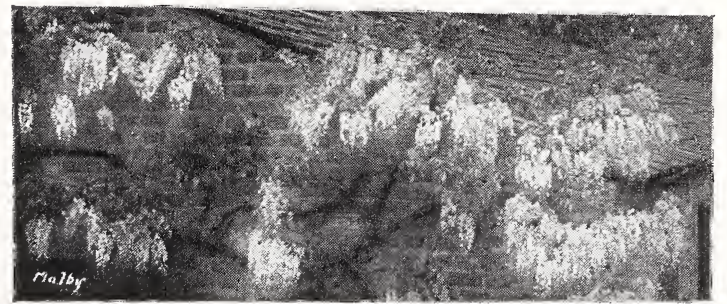

WISTARIA CHINENSIS 


\section{HEDGE PLANTS}

Berberis Thunbergii (Japan Barberry). Where a dwarf deciduous hedge is wanted, nothing equals this beautiful Barberry. Requires but little pruning to keep in shape. The leaves are small, light green, and towards fall assume rich, brilliant colors, the fruit or berries becoming scarlet. Absolutely hardy in all parts of the country. Plant 12 to 15 inches apart. Strong, bushy plants, $12^{\prime \prime}$ to $18^{\prime \prime}$.

Each 35c; doz. \$3.50; $100 \$ 28.00$

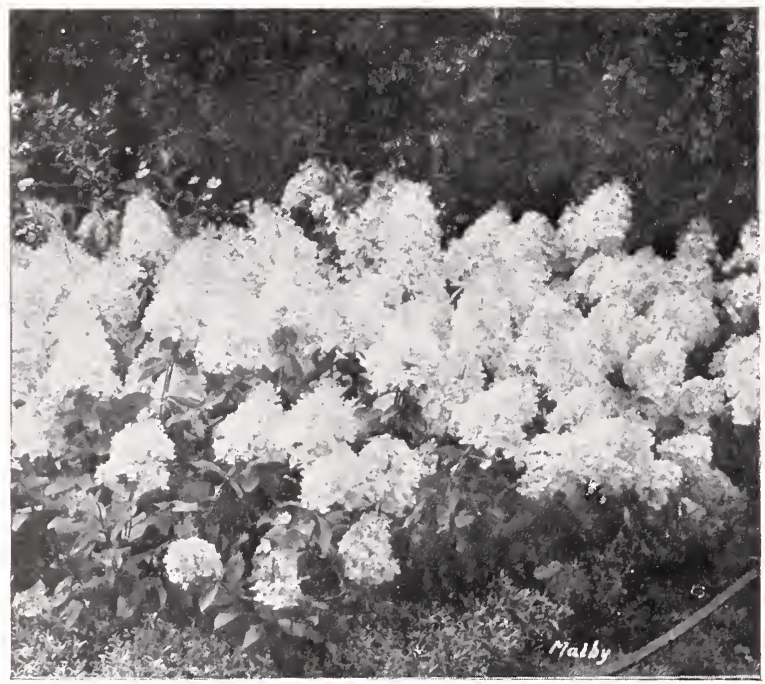

HYDRANGEA PANICULATA.

Hydrangea Paniculata. Tens of thousands of this noble summer and autumn-flowering shrub have been sold the past few years, and the demand is now universal. They grow to a height of 8 to 10 feet, and are absolutely hardy, grow in any soil and bloom the same year they are set out. They flower abundantly, bearing immense panicles of bloom a foot long, white at first, turning to rose in autumn, commencing to bloom in August, when very few shrubs are in bloom. An annual shortening of branches is necessary to increase the size of the flowers.

Each 60c; doz. $\$ 6.00$

Privet (California or broad oval-leaved). Best of all hedge plants. The Privet is now one of the best-known shrubs, both for hedging and for ornamental planting on the lawn. All of the varieties offered have merit, some for their foliage, some for their berries. They are almost evergreen and of dense habit, and bear shearing to any extent. 18" to $24^{\prime \prime}$

Doz. $\$ 1.00 ; 100 \$ 6.00$ (by express, collect) 


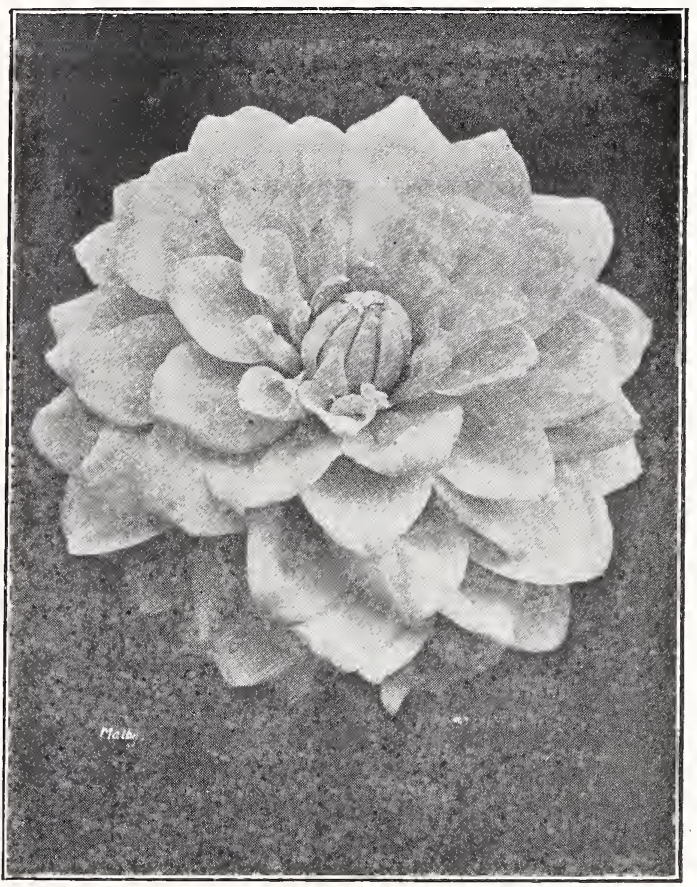

\section{DAHLIAS}

The Dahlia is an old garden favorite, because of its wonderful size and brilliancy in the garden, and its extreme beauty and decorative value when cut for use in the home.

Modern Dahlias introduced within the past few years are very difficult to describe, in fact one has to see them to realize the perfection of form, the wonderful colors, and the size to which they can be grown.

We have devoted much of our time to the growing of Dahlias, and offer in the following list an upto-date collection of some of the best in cultivation.

The letters following each name denote the class to which each variety belongs:
(C.) $=$ Cactus.
$($ Dec. $)=$ Decorative.
(H.C. $)=$ Hybrid Cactus
(P.) = Peony Type.
$($ Pom. $)=$ Pompon
(S.) $=$ Show.

Each

Ambassador (C.). Soft buff, shaded with salmon; large, perfect flowers, on strong, straight stem ...............\$2.00

Attraction (H. C.). Lovely rosy lilac; large

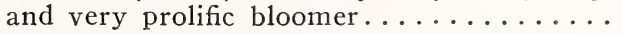

Deelighted (S.). Another very good sort to grow for cutting. Color is pure white... 


\section{Dahlias-Continued}

Elsie Burgess (S.). A charming blend of Each white, tipped with lavender; splendid for

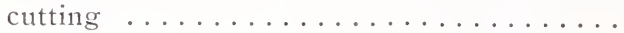

Francis Lobdell (H. C.). Large upright flower of pale rose, shading to a white center. One of the best in its class...........

Hortulanus Fiet (Dec.). A broad petaled, giant flower of brilliant shrimp red and old gold.

Jack Rose (Dec.). An old, yet very popular variety; deep crimson with maroon shadings

Jersey's Beauty (Dec.). One of the greatest Dahlias ever raised. Flowers are perfect in form, of a beautiful rich pink, held straight up on a strong stem. This is one you'll

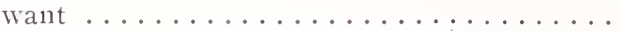

Judge Marean (Dec.). A beautiful blend of salmon, orange and yellow; flower is of perfect form, borne upright............

Millionaire (Dec.). Delicate lavender, suffused with pink; very showy............

Mrs. I. de Ver Warner (Dec.). This Dahlia is popular and does well all over the country. Flowers are perfectly formed, of a charming shade of mauve pink..............

Patrick O'Mara (Dec.). A large flower of rich orange and gold. A splendid variety for cutting.................

Sylvia (Dec.). Well known and still grown largely for its cut-flower qualities; it is a

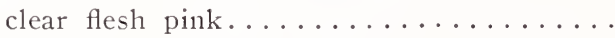

A. D. Livoni (S.). Rich rosy-pink; perfect flowers, with quilled petals, that overlap nicely ...................

Ballet Girl (C.). A perfect example of the Cactus type; large flowers of gold and orange, shaded white.............

Bianca (C.). A lovely blend of pink and lavender; splendid for cutting.......... 


\section{Dahlias-Continued}

Contrast (H. C.). A brilliant Dahlia. Flowers are bright and scarlet, each petal tipped

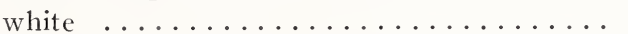

Diana (H. C.). Rich, deep crimson with violet reverse. Large, handsome flower....

Edith Carter (C.). Large flower of golden yellow, suffused with carmine; very attrac-

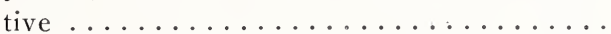

Extase (C.). A blend of white and mauve, the latter intensified at tips of petals.....

Gladys Sherwood (H. C.). One of the largest of all white H. C. Dahlias. Flowers are very full, and held well on strong stem...

Golden West (C.). A grand blend of canary

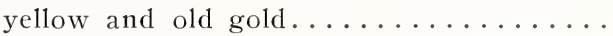

J. Herbert Alexander (C.). Delicate salmonpink, blended with yellow; very fascinating color ................................

Madonna (H. C.). A pure white variety, very useful for cutting..............

Miramoto (H. C.). Large flower of fine form; color is rich, velvety, crimson-scarlet.....

Mrs. Edna Spencer (C.). A lovely shade of delicate orchid-pink; a great favorite.....

Mrs. Warnaar (H. C.). Large flower of delicate ivory white; very prolific bloomer;

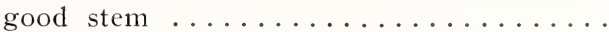

Mina Burgle (Dec.). A fine garden Dahlia. Color is rich dazzling scarlet.........

Princess Juliana (Dec.). Lovely flower of pure snow-white; free bloomer.........

Samaritan (C.). A very fine cactus type, of

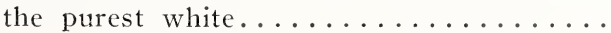

The Emperor (Dec.). A huge bloom, perfectly formed of broad flat petals; color is deep maroon, with a chocolate sheen........

\section{Pompon Dahlias}

Unnamed varieties, in separate colors; red, white or pink. One of the grandest of flowers for table and other decorations......

(Any three Pompons for 75c.) 


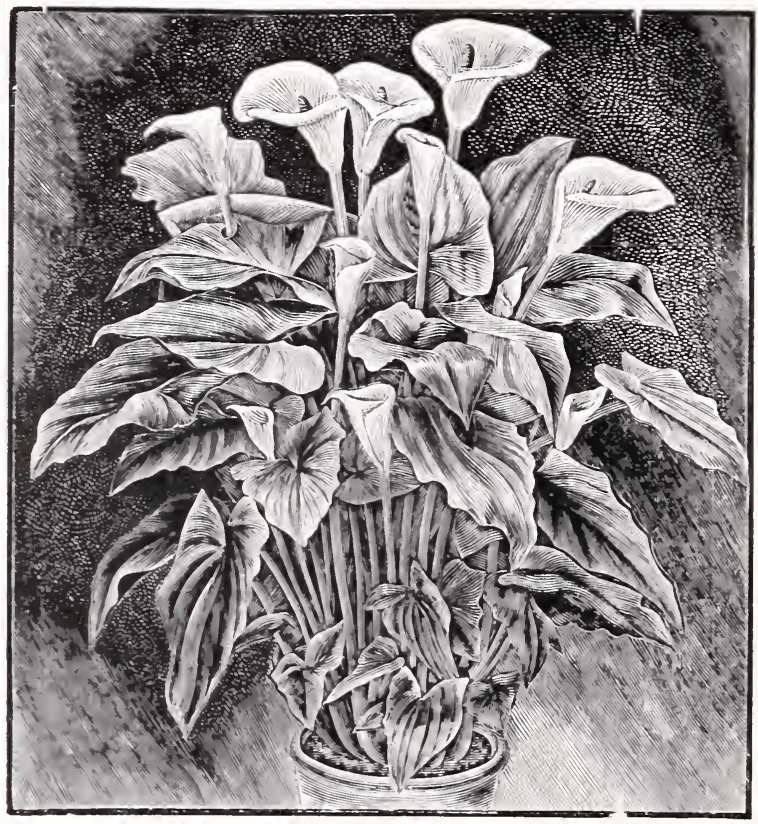

CALLA LILY

\section{Miscellaneous Bulbs}

HYACINTHUS (Galtonia) Candicans. A noble plant bearing in late summer massive spikes of from 40 to 50 snow-white, bell-shaped flowers. Each 20c; doz. \$2.00

CALLA, Mrs. Roosevelt. Remarkable for its spotted foliage; flowers are white, tinged amber.

Each 35c; doz. \$3.50

Golden Roosevelt. (New 1925.) A very uncommon variety, of a deeper shade of gold than the preceding.

Each \$1.00

Rehmannii. A rare shade in Callas; flowers are clear pink, borne on rather dwarf stems.

Each \$1.00

TIGRIDIA Pavonia (Tiger or Shell Flower). A semi-hardy bulb requiring same treatment as Gladioli. Grows about 18 in. to $2 \mathrm{ft}$. high, bearing wide open 3 -lobed flowers of bright red, spotted yellow and purple.

Each 40c; doz. \$4.00

TUBEROSE "The Pearl." This flower is fairly popular, on account of its pure white color, and delightful fragrance. Our stock is very healthy and true.

Each 10c; doz. \$1.00 


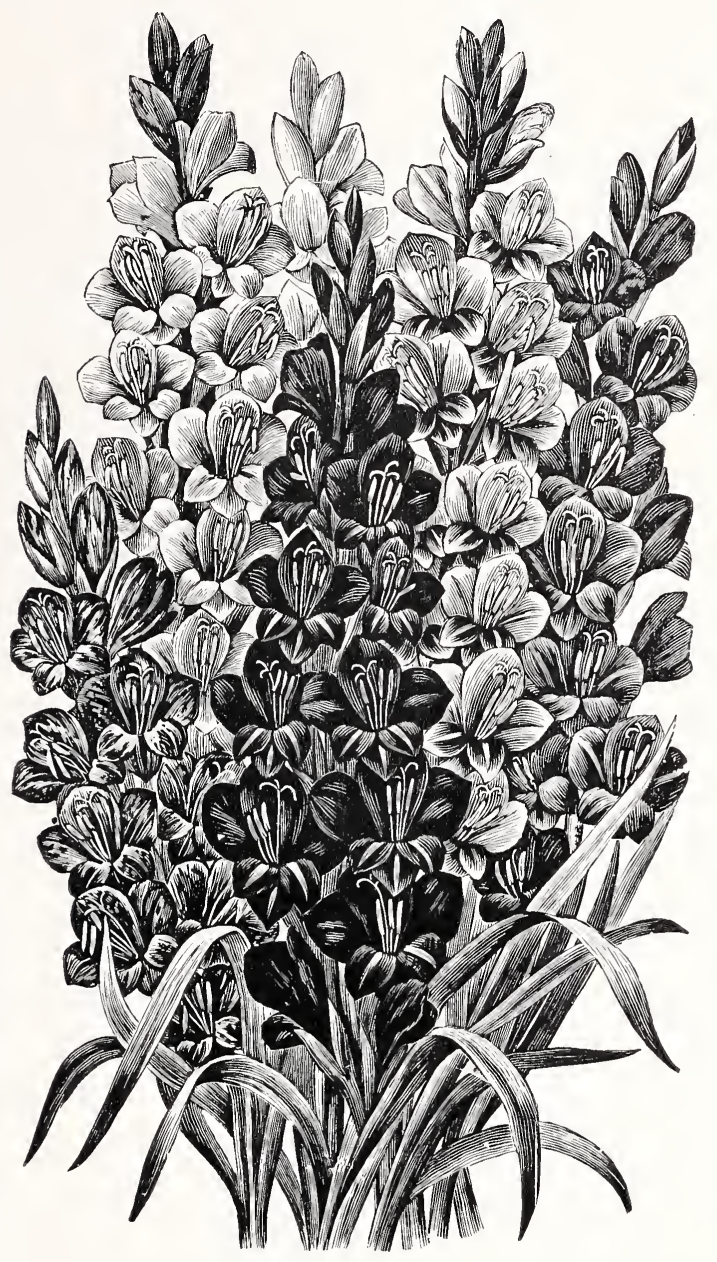

Our "Surprise" collection of Gladioli, offered on page 14, is, we believe, the greatest value ever offered; many really fine varieties are contained in this mixture, and we are sure that those who plant these liberally, for cutting, will find a carefully blended assortment of practically all colors known in Gladioli. 


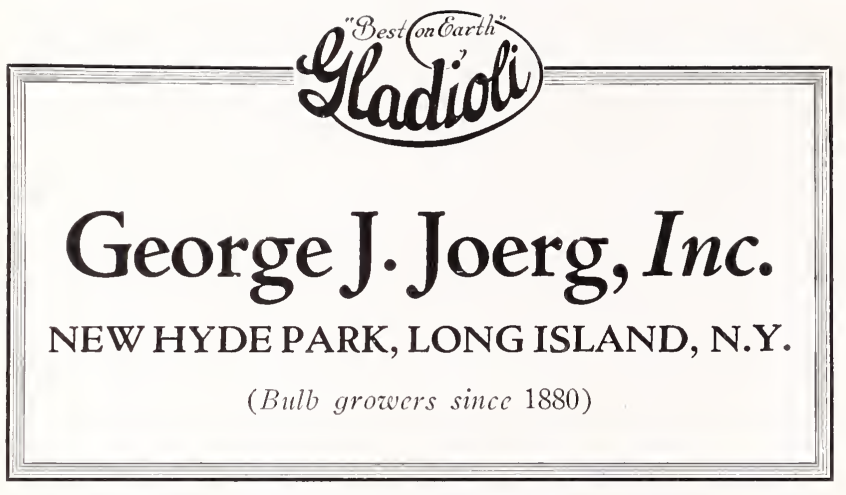

